\title{
Lactate Production and Absence of Gluconeogenesis from Placental Transferred Substrates in Fetuses from Fed and 48-H Starved Rats
}

\author{
MANUEL PALACIN, MIGUEL A. LASUNCIÓN, AND E. HERRERA \\ Departamento de Investigación, Hospital Ramón y Cajal [M.P., M.A.L., E.H.], Departamento de Bioquimica, \\ Facultad de Medicina, Universidad de Alcalá de Henares [M.A.L., E.H.], Madrid, Spain
}

\begin{abstract}
Fed and 48-h starved rats were infused on day 21.5 of gestation for 20 min through the left uterine artery with $\left[\mathrm{U}_{-}-{ }^{14} \mathrm{C}-\right]-\mathrm{D}$-glucose, $\left[\mathrm{U}-{ }^{14} \mathrm{C}\right]$-glycerol, or $\left[\mathrm{U}-{ }^{14} \mathrm{C}\right]$ - $\mathrm{L}$-alanine. The mother and fetuses from both uterine horns were processed separately for radioactivity measurements in plasma and liver. Differences in radioactivity values between fetuses from the left and the right sides are used as indexes of placental transference of the infused tracers prior to their distribution and transformation in the maternal circulation. After infusion of $\left[\mathrm{U}^{1{ }^{14}} \mathrm{C}\right]$-D-glucose, $\left[\mathrm{U}_{-}{ }^{14} \mathrm{C}\right]$ -glycerol, or $\left[\mathrm{U}^{-14} \mathrm{C}\right]-\mathrm{L}$-alanine, plasma radioactivity values and specific activities corresponding to the respective infused tracer appeared much higher in fetuses from the left than the right uterine side. Plasma ${ }^{14} \mathrm{C}$-lactate values also were higher in the left than the right fetuses indicating that fetoplacental structures produced lactate from those placentally transferred ${ }^{14} \mathrm{C}$-metabolites. No difference in plasma ${ }^{14} \mathrm{C}$-glucose between left and right uterine horn fetuses was observed after maternal infusion with either $\left[\mathrm{U}-{ }^{14} \mathrm{C}\right]$-glycerol or $\left[\mathrm{U}^{-14} \mathrm{C}\right]-\mathrm{L}$-alanine, either in fed or 48-h starved rats. In the mother both $\left[U-{ }^{14} \mathrm{C}\right]$-glycerol and $[\mathrm{U}$ ${ }^{14} \mathrm{Cl}$-L-alanine were efficiently converted to ${ }^{14} \mathrm{C}$-glucose, and this process was significantly enhanced with starvation. ${ }^{14} \mathrm{C}$-fatty acids present in fetal liver after maternal infusions with either $\left[\mathrm{U}-{ }^{14} \mathrm{C}\right]-\mathrm{D}$-glucose or $\left[\mathrm{U}-{ }^{14} \mathrm{C}\right]$-glycerol were decreased by starvation whereas no fatty acid synthesis from $\left[\mathrm{U}-{ }^{14} \mathrm{C}\right]-\mathrm{L}$-alanine was detected. Much less ${ }^{14} \mathrm{C}$-glyceride glycerol was found in fetal liver after maternal infusions of $\left[\mathrm{U}-{ }^{14} \mathrm{C}\right]-\mathrm{D}$-glucose than $\left[\mathrm{U}^{14}{ }^{14} \mathrm{C}\right]$-glycerol, and its incorporation was unaffected by maternal starvation. Results show the significant production by the fetoplacental unit of lactate from transferred maternal substrates and the absence of gluconeogenesis in the rat fetus even after $48 \mathrm{~h}$ of maternal food deprivation. Lack of gluconeogenesis occurred even above the triose phosphate step and despite the fact that glycerol phosphorylation is active in fetal liver, indicating that maternal glucose is the only source of this metabolite for the normal rat fetus. (Pediatr Res 22: 6-10, 1987)
\end{abstract}

In the rat fetus unlike several other species including the guinea pig (1), rabbit (2), sheep (3), and man (4) gluconeogenesis is

Received November 29, 1985; accepted January 28, 1987.

Correspondence Prof. Emilio Herrera, Ph.D., Departamento de Investigación, Hospital Ramón y Cajal, Ctra. de Colmenar, km 9, 28034, Madrid, Spain.

Supported by a grant from the Fondo de Investigaciones Sanitarias de la Seguridad Social, Spain. absent and develops only after birth (5-8) as a consequence of the induction of cytosolic phosphoenolpyruvate carboxykinase $(1,9)$. Due to the conversion of administered $\left[1-{ }^{14} \mathrm{C}\right]$-glycerol to ${ }^{14} \mathrm{C}$-glucose (10) it has been proposed that the gluconeogenetic pathway is functional in the rat fetus above the triose phosphate step, but in other studies gluconeogenesis from glycerol was not detected in in vitro (11) or in vivo (12) rat fetus preparations. Maternal fasting has been reported to induce gluconeogenesis prematurely in the rat fetus (13-15), but this finding has not been consistent and no change in fetal liver gluconeogenic activities were reported after $48 \mathrm{~h}$ of maternal fasting (16). In addition, no changes were detected in fetal liver lipogenic enzymes after maternal fasting (16) whereas fetal lipogenesis from ${ }^{3} \mathrm{H}_{2} \mathrm{O}$ was inhibited (17). In order to clarify these controversies, the present study was performed to determine the comparative in vivo metabolic fate of D-glucose, L-alanine, and glycerol in fetuses from fed and 48-h starved late pregnant rats. Labeled substrates were infused through the maternal left uterine artery according to our recently described technique (18) for placental transfer studies which allows determination of the metabolic fate of substrates in the rat fetus independently of interconversions occurring in the mother.

\section{METHODS}

Wistar female rats, mated when weighing 170-190 g, were studied at day 21.5 of gestation (estimated by the appearance of spermatozoids in vaginal smears) comparing fed and 48 -h fooddeprived animals. Rats were anesthesized with sodium pentobarbital (33 mg/ $\mathrm{kg}$ body weight, intravenous) and operated according to our previously reported surgical procedure (18). Briefly, a PE-10 cannula (Intramedic) was introduced counter current into the left external iliac artery to the beginning of the superior vesical artery which was clamped distal to the left uterine artery exit level. The infusion medium introduced through the cannula therefore combines with the blood circulating through the left uterine artery. Rats were infused for $20 \mathrm{~min}$ at a constant rate of $12.5 \mu \mathrm{l} / \mathrm{min}$ with $250 \mu \mathrm{l}$ of a $0.9 \% \mathrm{NaCl}$ solution containing 10 $\mu \mathrm{Ci}$ of $\left[\mathrm{U}-{ }^{14} \mathrm{C}\right]$-D-glucose, $\left[\mathrm{U}-{ }^{14} \mathrm{C}\right]-\mathrm{L}$-alanine, or $\left[\mathrm{U}-{ }^{14} \mathrm{C}\right]$-glycerol (The Radiochemical Center, Amersham, England) (specific activity 257,10 and $171 \mathrm{mCi} / \mathrm{mmol}$, respectively).

After collection of blood from the maternal aorta into heparinized syringes, placentas and fetuses from the left and right uterine horns were immediately excised. Fetuses were decapitated and blood collected into heparinized receptacles. All fetal blood from each uterine side was pooled separately. Fetal livers were immediately placed in liquid $\mathrm{N}_{2}$. Plasma aliquots were deproteinized with $10 \%$ perchloric acid and neutralized with saturated potas. sium bicarbonate. Protein-free supernatants were used for esti- 
mation of glucose (19), alanine (20), glycerol (21), and lactate (22). In experiments with infusions of $\left[\mathrm{U}-{ }^{14} \mathrm{C}\right]$-D-glucose or [U$\left.{ }^{14} \mathrm{C}\right]$-L-alanine, labeled plasma glucose, alanine, and lactate were purified (23) from $100-\mu l$ aliquots of deproteinized supernatants, using microcolumns made with AG 1- $\times 8200-400$ chloride and AG 50 W-8 200-400 H $\mathrm{H}^{+}$(Bio-Rad Laboratories, Richmond, CA) rinsed with distilled water, $0.5 \mathrm{M}$ formic acid, and $2 \mathrm{~N}$ ammonium hydroxyde for ${ }^{14} \mathrm{C}$-glucose, ${ }^{14} \mathrm{C}$-lactate and ${ }^{14} \mathrm{C}$-alanine elutions, respectively. Eluates were collected in counting vials and lyophilized for counting. Recoveries for $\left[\mathrm{U}-{ }^{14} \mathrm{C}\right]$-D-glucose added to plasma before precipitation were $97 \pm 2 \%$ in the first eluate, $88 \pm 3 \%$ for $\left[\mathrm{U}-{ }^{14} \mathrm{C}\right]-\mathrm{L}$-lactate in the second eluate, and $91 \pm 2 \%$ for $\left[\mathrm{U}-{ }^{14} \mathrm{C}\right]$-L-alanine in the third eluate. Tracer recoveries in the noncorresponding eluates were always below $0.4 \%$.

In experiments with $\left[\mathrm{U}-{ }^{14} \mathrm{C}\right]$-glycerol infusions, labeled plasma glycerol, glucose, and lactate were purified by ascendent paper chromatography, the eluent being the upper phase resulting from the butanol-water-methanol-formic acid mixture $(320: 320: 80: 1)$ $(v / v)(24)$. The spots were identified by running purified standards in parallel and cutting them into small pieces for introduction into counting vials. Recoveries of labeled glycerol, glucose, and lactate were $86 \pm 0.5 \%, 92 \pm 1 \%$, and $90 \pm 0.5 \%$, respectively. Labeled lipids in fetal liver were extracted (25) and saponified in ethanolic $1 \mathrm{~N}$ potassium hydroxide for fatty acid and glyceride glycerol fractionation (26). Radioactivity counting was done by means of a Normascint-22 cocktail (Scharlau, Barcelona, Spain) in a LS 3800 Beckman counter. Radioactivity values were corrected by considering $1 \times 10^{6} \mathrm{dpm}$ as the total infused radioactivity per rat. Results were expressed as means \pm SD and statistical comparison between groups was performed by the Student's $t$ test.

\section{RESULTS}

Pregnant rats in the 21.5 day of gestation were infused for 20 min with tracer amounts of three different labeled metabolites through the left uterine artery to determine their appearance and potential transformation in the respective fetuses. The steady state concentration in plasma of these metabolites and lactate was measured in mothers and their fetuses at the end of the infusions and values are shown in Table 1. Plasma glucose and glycerol concentrations were higher and alanine and lactate levels were lower in fed and 48-h starved mothers than in their respective fetuses. Maternal starvation caused a decrease in maternal plasma glucose and alanine and a slight increase in plasma glycerol concentrations whereas in fetuses the only change detected with starvation was a significant reduction in plasma alanine (Table 1).

After infusion of labeled metabolites through the left maternal uterine artery, radioactivity in fetuses from the left uterine side comprised the amounts transferred from directly infused tracer and coming from the maternal circulation; whereas in fetuses from the right uterine side radioactivity corresponded only to the amount coming from maternal circulation, e.g. the infused tracer diluted in general maternal circulation and labeled products of metabolization. The difference between radioactivity values in left and right fetuses therefore provides an index of direct availability to the fetus of placentally transferred substrates from the infused medium.

These values and those of maternal plasma after the infusion with $\left[\mathrm{U}-{ }^{14} \mathrm{C}\right]$-D-glucose, $\left[\mathrm{U}-{ }^{14} \mathrm{C}\right]$-glycerol, or $\left[\mathrm{U}-{ }^{14} \mathrm{C}\right]$-L-alanine through the left uterine artery are shown in Tables 2 to 4 , respectively. After maternal infusion with $\left[\mathrm{U}-{ }^{14} \mathrm{C}\right]-\mathrm{D}-\mathrm{glucose}$, plasma ${ }^{14} \mathrm{C}$-glucose level and its specific activity were much higher in fetuses from the left uterine side than from the right side (Table 2). Similarly, the amount of ${ }^{14} \mathrm{C}$-lactate and its specific activity in fetal plasma were significantly greater in the left than in the right fetuses. Interestingly, ${ }^{14} \mathrm{C}$-lactate plasma values in left fetuses were much higher than the mother's (Table 2). Maternal starvation did not modify these relationships although it significantly increased the amount of ${ }^{14} \mathrm{C}$-glucose present in maternal plasma and its specific activity (Table 2). As shown in Table 3, when $\left[\mathrm{U}-{ }^{14} \mathrm{C}\right]$-glycerol was the tracer infused through the maternal left uterine artery both ${ }^{14} \mathrm{C}$-glycerol and ${ }^{14} \mathrm{C}$-lactate plasma values and their specific activities were significantly higher in the left than in the right fetuses whereas ${ }^{14} \mathrm{C}$-glucose levels and ${ }^{14} \mathrm{C}$ glucose specific activity did not differ between fetuses from both sides (Table 3 ).

Much more radioactivity appeared as ${ }^{14} \mathrm{C}$-glucose than as ${ }^{14} \mathrm{C}$ glycerol in maternal plasma after maternal infusion with $\left[\mathrm{U}-{ }^{14} \mathrm{C}\right]-$ glycerol and this difference was even greater in the 48-h starved rat (Table 3). Plasma ${ }^{14} \mathrm{C}$-glucose values did not differ between fetuses from either side whereas both ${ }^{14} \mathrm{C}$-glycerol and ${ }^{14} \mathrm{C}$-lactate levels and their respective specific activities were significantly higher in fetuses from the left versus the right uterine side in both the fed and the starved condition after maternal infusion with $\left[\mathrm{U}-{ }^{14} \mathrm{C}\right]$-glycerol (Table 3 ). As shown in Table 4, after maternal infusion of $\left[\mathrm{U}-{ }^{14} \mathrm{C}\right]$-L-alanine through the left uterine artery, plasma ${ }^{14} \mathrm{C}$-alanine levels appeared higher in fetuses from the left uterine side than in their mothers either fed or starved. Left fetuses showed higher plasma ${ }^{14} \mathrm{C}$-alanine and ${ }^{14} \mathrm{C}$-lactate values as well as ${ }^{14} \mathrm{C}$-alanine specific activity than the right ones after maternal infusion with $\left[\mathrm{U}-{ }^{14} \mathrm{C}\right]-\mathrm{L}$-alanine when either fed or starved. On the contrary, ${ }^{14} \mathrm{C}$-glucose levels in fetuses were very low and no differences were observed between those from the left and the right uterine sides (Table 4). As it occurred with $\left[\mathrm{U}-{ }^{14} \mathrm{C}\right]$-glycerol, after the infusion with $\left[\mathrm{U}-{ }^{14} \mathrm{C}\right]-\mathrm{L}$-alanine, maternal ${ }^{14} \mathrm{C}$-glucose values and specific activity were significantly higher in 48-h starved than in fed rats (Table 4).

Labeled lipid levels in fetal liver after maternal infusion of the labeled metabolites were measured and values are summarized in Table 5. [U- $\left.{ }^{14} \mathrm{C}\right]$-D-glucose and $\left[\mathrm{U}-{ }^{14} \mathrm{C}\right]$-glycerol produced higher radioactivity values of both ${ }^{14} \mathrm{C}$-fatty acids and ${ }^{14} \mathrm{C}$-glyceride glycerol in the liver of fetuses from the left versus the right uterine horn (Table 5). Maternal starvation diminished ${ }^{14} \mathrm{C}$-fatty

Table 1. Glucose, glycerol, alanine, and lactate* concentrations in mother's and fetus' plasma after maternal infusion with $D-1 U$ ${ }^{14} \mathrm{C} /$-glucose, $\left[U-{ }^{14} \mathrm{C}\right]$-glycerol, or $L-\left[U-{ }^{14} \mathrm{C}\right]$-alanine, respectively, in 21.5 -day pregnant rat

\begin{tabular}{|c|c|c|c|c|c|c|}
\hline & \multicolumn{3}{|c|}{ Fed rats } & \multicolumn{3}{|c|}{ 48-h starved rats } \\
\hline & Mothers & Fetuses & $p \dagger$ & Mothers & Fetuses & $p$ \\
\hline Glucose (mmol/liter) & $4.9 \pm 0.7(6) \ddagger$ & $3.9 \pm 0.4(6)$ & $<0.05$ & $4.1 \pm 0.2 \S(6)$ & $3.6 \pm 0.2(6)$ & $<0.01$ \\
\hline Glycerol ( $\mu \mathrm{mol} /$ liter $)$ & $155 \pm 40(6)$ & $113 \pm 29(6)$ & NS & $182 \pm 58(6)$ & $122 \pm 20(6)$ & NS \\
\hline Alanine ( $\mu \mathrm{mol} /$ liter $)$ & $479 \pm 47(6)$ & $1667 \pm 425(6)$ & $<0.001$ & $292 \pm 82 \|(5)$ & $1072 \pm 280 \S(5)$ & $<0.001$ \\
\hline Lactate (mmol/liter) & $3.2 \pm 1.2(18)$ & $13.2 \pm 4.1(18)$ & $<0.001$ & $3.0 \pm 0.8(17)$ & $13.0 \pm 6.4(17)$ & $<0.001$ \\
\hline
\end{tabular}

* Lactate values correspond to all animals studied.

$\uparrow$ Statistical comparisons between mothers and fetuses.

$\ddagger$ Mean \pm SD. Numbers in parentheses are numbers of rats/group.

Statistical comparisons between fed and 48-h starved rats: $\S p<0.05 ; \| p<0.01$. 
Table 2. Plasma radioactivity values in mothers and fetuses after maternal infusion through left uterine artery with $D-\left[U-{ }^{14} C J\right.$ glucose in 21.5-day pregnant rat

\begin{tabular}{|c|c|c|c|c|c|c|c|c|}
\hline & \multicolumn{4}{|c|}{ Fed rats } & \multicolumn{4}{|c|}{ 48-h starved rats } \\
\hline & Mothers & Left fetuses & $\begin{array}{c}\text { Right } \\
\text { fetuses }\end{array}$ & $p^{*}$ & Mothers & Left fetuses & $\begin{array}{l}\text { Right } \\
\text { fetuses }\end{array}$ & $p$ \\
\hline${ }^{14} \mathrm{C}$-glucose $(\mathrm{dpm} / \mathrm{ml})$ & $4479 \pm 562 \dagger$ & $4495 \pm 1238$ & $1236 \pm 300$ & $<0.001$ & $6038 \pm 1070 \ddagger$ & $6984 \pm 4315$ & $1528 \pm 734$ & $<0.01$ \\
\hline $\begin{array}{l}{ }^{14} \mathrm{C} \text {-glucose specific activity } \\
(\mathrm{dpm} / \mu \mathrm{mol})\end{array}$ & $915 \pm 161$ & $1289 \pm 562$ & $347 \pm 138$ & $<0.001$ & $1472 \pm 281 \div$ & $1786 \pm 803$ & $374 \pm 190$ & $<0.01$ \\
\hline${ }^{14} \mathrm{C}$-lactate $(\mathrm{dpm} / \mathrm{ml})$ & $818 \pm 112$ & $5296 \pm 807$ & $1355 \pm 341$ & $<0.001$ & $833 \pm 408$ & $7111 \pm 3334$ & $1271 \pm 575$ & $<0.001$ \\
\hline $\begin{array}{l}{ }^{14} \mathrm{C} \text {-lactate specific activity } \\
(\mathrm{dpm} / \mu \mathrm{mol})\end{array}$ & $305 \pm 94$ & $495 \pm 156$ & $133 \pm 29$ & $<0.001$ & $288 \pm 127$ & $370 \pm 172$ & $123 \pm 94$ & $<0.05$ \\
\hline
\end{tabular}

* Statistical comparisons between left and right fetuses.

$\dagger$ Mean \pm SD of six rats/group.

Statistical comparisons between fed and 48-h starved rats: $\ddagger p<0.05$.

Table 3. Plasma radioactivity values in mothers and fetuses after maternal infusion through left uterine artery with $\left[U-{ }^{14} C\right]-g l y c e r o l$ in 21.5-day pregnant rat

\begin{tabular}{|c|c|c|c|c|c|c|c|c|}
\hline & \multicolumn{4}{|c|}{ Fed rats } & \multicolumn{4}{|c|}{ 48-h starved rats } \\
\hline & Mothers & Left fetuses & $\begin{array}{l}\text { Right } \\
\text { fetuses }\end{array}$ & $p^{*}$ & Mothers & Left fetuses & $\begin{array}{l}\text { Right } \\
\text { fetuses }\end{array}$ & $p$ \\
\hline${ }^{14} \mathrm{C}$-glycerol $(\mathrm{dpm} / \mathrm{ml})$ & $630 \pm 212 \dagger$ & $569 \pm 366$ & $47 \pm 60$ & $<0.01$ & $768 \pm 294$ & $835 \pm 493$ & $40 \pm 54$ & $<0.01$ \\
\hline $\begin{array}{l}{ }^{14} \mathrm{C} \text {-glycerol specific activity } \\
(\mathrm{dpm} / \mu \mathrm{mol})\end{array}$ & $4045 \pm 2139$ & $4780 \pm 2393$ & $390 \pm 335$ & $<0.001$ & $4355 \pm 1376$ & $6044 \pm 2201$ & $371 \pm 504$ & $<0.001$ \\
\hline${ }^{14} \mathrm{C}$-glucose $(\mathrm{dpm} / \mathrm{ml})$ & $3387 \pm 386$ & $691 \pm 120$ & $550 \pm 96$ & NS & $4625 \pm 743 \ddagger$ & $926 \pm 288$ & $877 \pm 190 \ddagger$ & NS \\
\hline $\begin{array}{l}{ }^{14} \mathrm{C} \text {-glucose specific activity } \\
(\mathrm{dpm} / \mu \mathrm{mol})\end{array}$ & $685 \pm 69$ & $170 \pm 45$ & $166 \pm 69$ & NS & $1190 \pm 143 \S$ & $268 \pm 47$ & $230 \pm 45$ & NS \\
\hline${ }^{14}$ C-lactate $(\mathrm{dpm} / \mathrm{ml})$ & $878 \pm 185$ & $1954 \pm 299$ & $922 \pm 201$ & $<0.001$ & $1019 \pm 274$ & $1733 \pm 314$ & $982 \pm 281$ & $<0.001$ \\
\hline $\begin{array}{l}{ }^{14} \mathrm{C} \text {-lactate specific activity } \\
(\mathrm{dpm} / \mu \mathrm{mol})\end{array}$ & $373 \pm 149$ & $129 \pm 18$ & $87 \pm 36$ & $<0.001$ & $705 \pm 314 \|$ & $133 \pm 29$ & $89 \pm 25$ & $<0.05$ \\
\hline
\end{tabular}

* Statistical comparisons between left and right fetuses.

$\dagger$ Mean \pm SD of six rats/group.

Statistical comparisons between fed and 48-h starved rats: $\ddagger p<0.01 ; \S p<0.001 ; \| p<0.05$.

Table 4. Plasma radioactivity values in mothers and fetuses after maternal infusion through left uterine artery with $L-\left[U-_{-}^{14} C\right]-$ alanine in 21.5-day pregnant rat

\begin{tabular}{|c|c|c|c|c|c|c|c|c|}
\hline & \multicolumn{4}{|c|}{ Fed rats } & \multicolumn{4}{|c|}{ 48-h starved rats } \\
\hline & Mothers & Left fetuses & $\begin{array}{l}\text { Right } \\
\text { fetuses }\end{array}$ & $p^{*}$ & Mothers & Left fetuses & $\begin{array}{l}\text { Right } \\
\text { fetuses }\end{array}$ & $p$ \\
\hline${ }^{14} \mathrm{C}$-alanine $(\mathrm{dpm} / \mathrm{ml})$ & $1021 \pm 321 \dagger$ & $6697 \pm 2533$ & $433 \pm 87$ & $<0.001$ & $1177 \pm 296$ & $5463 \pm 2518$ & $441 \pm 98$ & $<0.001$ \\
\hline $\begin{array}{l}{ }^{14} \mathrm{C} \text {-alanine specific activity } \\
(\mathrm{dpm} / \mu \mathrm{mol})\end{array}$ & $2152 \pm 664$ & $3647 \pm 1628$ & $304 \pm 74$ & $<0.01$ & $4346 \pm 1634 \ddagger$ & $4232 \pm 1290$ & $514 \pm 112 \ddagger$ & $<0.01$ \\
\hline${ }^{14} \mathrm{C}$-glucose $(\mathrm{dpm} / \mathrm{ml})$ & $627 \pm 76$ & $286 \pm 89$ & $274 \pm 40$ & NS & $1582 \pm 160 \S$ & $480 \pm 150$ & $417 \pm 94$ & NS \\
\hline $\begin{array}{l}{ }^{14} \mathrm{C} \text {-glucose specific activity } \\
(\mathrm{dpm} / \mu \mathrm{mol})\end{array}$ & $97 \pm 38$ & $51 \pm 16$ & $66 \pm 9$ & NS & $292 \pm 56 \|$ & $135 \pm 122$ & $119 \pm 40 \|$ & NS \\
\hline${ }^{14} \mathrm{C}$-lactate $(\mathrm{dpm} / \mathrm{ml})$ & $861 \pm 96$ & $6535 \pm 2611$ & $819 \pm 132$ & $<0.001$ & $896 \pm 76$ & $4160 \pm 2158$ & $829 \pm 208$ & $<0.001$ \\
\hline $\begin{array}{l}{ }^{14} \mathrm{C} \text {-lactate specific activity } \\
(\mathrm{dpm} / \mu \mathrm{mol})\end{array}$ & $212 \pm 47$ & $341 \pm 167$ & $58 \pm 18$ & $<0.01$ & $346 \pm 212$ & $260 \pm 122$ & $70 \pm 28$ & $<0.05$ \\
\hline
\end{tabular}

* Statistical comparisons between left and right fetuses

$\dagger$ Means \pm SD of six (fed) or five (starved) rats/group.

Statistical comparisons between fed and 48-h starved rats: $\ddagger p<0.01 ; \S p<0.001 ; \| p<0.05$.

acids without affecting ${ }^{14} \mathrm{C}$-glyceride glycerol (Table 5). Following infusion of $\left[\mathrm{U}-{ }^{14} \mathrm{C}\right]-\mathrm{D}$-glucose in fed pregnant rats, the radioactivity level was higher in liver fatty acids than in glyceride glycerol of left fetuses whereas this relationship was reversed when the mother was starved. Infusion of $\left[\mathrm{U}^{14}{ }^{14} \mathrm{C}\right]$-glycerol produced a much higher proportion of ${ }^{14} \mathrm{C}$-glyceride glycerol than ${ }^{14} \mathrm{C}$-fatty acids in fetal liver; this difference was more pronounced in fetuses from the left than from the right uterine horn (Table 5). Negligible amounts of radioactivity were found in fetal liver when the infused tracer was $\left[\mathrm{U}_{-}{ }^{14} \mathrm{C}\right]-\mathrm{L}$-alanine, and no differences in values were detected in fetuses from the left and right uterine horns.

\section{DISCUSSION}

Present results in rat fetuses from 21.5-day pregnant fed or 48h starved mothers support three basic conclusions: 1) significant gluconeogenesis does not occur from either glycerol or L-alanine; 2) a high proportion of these substrates and also D-glucose, when transferred from maternal circulation, reach the fetus in the form of lactate; and 3) the fetus responds to maternal starvation by decreasing liver fatty acid synthesis from transferred D-glucose and glycerol but not from $L$-alanine which is practically negligible as a lipogenic substrate for the rat fetus. Differences in radioac- 
Table 5. Labeled fatty acids and glyceride glycerol in fetal livers after maternal infusion through left uterine artery with $D-\left[U-{ }^{14} C\right]-$ glucose, $\left[U-{ }^{14} \mathrm{C}\right]$-glycerol, or $\mathrm{L}-\left[\mathrm{U}-{ }^{14} \mathrm{C}\right]$-alanine in 21.5-day pregnant rat

\begin{tabular}{|c|c|c|c|c|c|c|}
\hline & \multicolumn{3}{|c|}{ Fed rats } & \multicolumn{3}{|c|}{ 48-h starved rats } \\
\hline & $\begin{array}{c}\text { Left } \\
\text { fetuses }\end{array}$ & $\begin{array}{l}\text { Right } \\
\text { fetuses }\end{array}$ & $p^{*}$ & $\begin{array}{c}\text { Left } \\
\text { fetuses }\end{array}$ & $\begin{array}{c}\text { Right } \\
\text { fetuses }\end{array}$ & $p$ \\
\hline \multicolumn{7}{|l|}{ Infusion with $\mathrm{D}-\left[\mathrm{U}-{ }^{14} \mathrm{C}\right]$-glucose } \\
\hline${ }^{14} \mathrm{C}$-fatty acids $(\mathrm{dpm} / \mathrm{g})$ & $86 \pm 49+$ & $24 \pm 16$ & $<0.05$ & $4 \pm 4 \ddagger$ & $1 \pm 2 \ddagger$ & NS \\
\hline${ }^{14} \mathrm{C}$-glyceride glycerol (dpm/g) & $48 \pm 20$ & $21 \pm 11$ & $<0.05$ & $34 \pm 7$ & $8 \pm 4 \S$ & $<0.001$ \\
\hline \multicolumn{7}{|l|}{ Infusion with $\left[\mathrm{U}^{14} \mathrm{C}\right]$-glycerol } \\
\hline${ }^{14} \mathrm{C}$-fatty acids (dpm/g) & $91 \pm 42$ & $40 \pm 16$ & $<0.05$ & $19 \pm 18 \ddagger$ & $5 \pm 2 \ddagger$ & NS \\
\hline${ }^{14} \mathrm{C}$-glyceride glycerol $(\mathrm{dpm} / \mathrm{g})$ & $385 \pm 149$ & $86 \pm 60$ & $<0.01$ & $471 \pm 252$ & $45 \pm 13$ & $<0.01$ \\
\hline \multicolumn{7}{|l|}{ Infusion with $\mathrm{L},-\left[\mathrm{U}-{ }^{14} \mathrm{C}\right]$-alanine } \\
\hline${ }^{14} \mathrm{C}$-fatty acids (dpm/g) & $27 \pm 29$ & $19 \pm 20$ & NS & $18 \pm 16$ & $3 \pm 2$ & NS \\
\hline${ }^{14} \mathrm{C}$-glyceride glycerol (dpm/g) & $23 \pm 13$ & $22 \pm 13$ & NS & $50 \pm 42$ & $28 \pm 26$ & NS \\
\hline
\end{tabular}

* Statistical comparisons between left and right fetuses.

$\dagger$ Mean $\pm \mathrm{SD}$ of five to six rats/group.

Statistical comparisons between fed and 48-h starved rats: $\ddagger p<0.01 ; \S p<0.05$.

tivity between left and right fetuses for ${ }^{14} \mathrm{C}$-glucose,${ }^{14} \mathrm{C}$-glycerol, and ${ }^{14} \mathrm{C}$-alanine after maternal infusion through the left uterine artery with the respective uniformly ${ }^{14} \mathrm{C}$-labeled tracers, and the magnitude of these differences (the larger corresponding to ${ }^{14} \mathrm{C}$ alanine and the smaller to ${ }^{14} \mathrm{C}$-glycerol) are in agreement with the way it is known they cross the placenta $(10,27,28)$. Plasmaspecific activities of the respective tracers in fetuses from the left uterine side were also significantly higher than in those from the right ones, indicating that the infused tracer directly reached fetuses from the left side whereas it reached those from the right side after its dilution in maternal circulation. This explanation also justifies the fact that specific activities of infused metabolites were always lower in right fetuses than in their mothers. Present findings validate the technique used and reflect its suitability for the study of metabolic fate of placental transferred substrates in the rat.

After maternal infusion with $\left[\mathrm{U}-{ }^{14} \mathrm{C}\right]$-glycerol or $\mathrm{L}-\left[\mathrm{U}-{ }^{14} \mathrm{C}\right]-$ alanine a significant proportion of the label was converted into glucose by maternal tissues as indicated by the appearance of ${ }^{14} \mathrm{C}$-glucose in maternal plasma; the process was enhanced with starvation as expected. Glycerol was always a more efficient gluconeogenic substrate even when values were corrected by their respective specific activities in maternal plasma, substantiating previous findings in the late pregnant rat (29). In contrast, from either substrate no incorporation of ${ }^{14} \mathrm{C}$-atoms into glucose occurred in fetuses. Despite the fact that the amount of radioactivity of the infused tracers $\left({ }^{14} \mathrm{C}\right.$-glycerol or ${ }^{14} \mathrm{C}$-alanine) and their specific activities were much higher in plasma of left than of right fetuses, ${ }^{14} \mathrm{C}$-glucose values were statistically equal in fetuses from both sides (Tables 3 and 4 ). It may be concluded that fetal ${ }^{14} \mathrm{C}$-glucose is derived exclusively from the maternal circulation and that no fetal gluconeogenesis occurred either in the fed or the starved condition.

This conclusion is in agreement with reports based on different methodologies (5-8) but is in contradiction with results of other studies $(10,13,15)$, most of which $(13,15)$ used 4-day rather than 2-day starvation periods indicating that fetal gluconeogenesis is only induced after prolonged maternal food deprivation. In one study, in which the rat diet was not specified (10), gluconeogenesis from labeled glycerol was detected in the fetuses, but the tracer was injected into the fetus when exteriorized from the uterus. This greatly altered the environmental condition and the immediate and abnormally high glycerol load to the fetus could induce premature gluconeogenesis. Absence of gluconeogenesis in the rat fetus is probably a consequence of its limited phosphoenolpyruvate carboxykinase and glucose-6-phosphatase activities in the liver $(7,30)$, and when using L-alanine as substrate, reduced alanine aminotransferase activity (16) should also be taken into consideration.
Lack of ${ }^{14} \mathrm{C}$-glucose synthesis in the rat fetus is clearly in contrast with the efficient incorporation of ${ }^{14} \mathrm{C}$-atoms from either labeled glucose, glycerol, and alanine into fetal lactate which was shown in the present study by the much higher levels of ${ }^{14} \mathrm{C}$ lactate in the plasma of fetuses from the left than in those from the right side after maternal infusions through the left uterine artery. Findings indicate that ${ }^{14} \mathrm{C}$-lactate is synthesized from maternal transferred substrates by fetoplacental structures. Recently we reported the ability of rat placenta to synthesize lactate from both D-glucose (31) and L-alanine (32). Production of placental lactate from L-alanine seems to be involved in the mechanism of the maternofetal transfer of the amino acid (32) and is consistent with the reported presence of alanine aminotransferase in rat placenta $(16,33)$. The level of labeled lactate in fetal plasma after infusion through the maternal left uterine artery was much lower with $\left[\mathrm{U}-{ }^{14} \mathrm{C}\right]$-glycerol than with the other substrates studied. This may be due to the limited placental transfer of glycerol as compared with either D-glucose or L-alanine (34) as a result of the low concentration of glycerol in maternal circulation. Because of the rapid and efficient conversion of maternal glycerol into glucose (29), only a limited amount of glycerol is consequently available for transfer to the fetus, as previously proposed (35). Placental production of lactate from maternal transferred substrates is physiologically important as it contributes to the high lactate levels present in fetal plasma, and also because lactate is used by the rat fetus as an energy fuel ( 36 , 37). As pointed out by Kraan and Dias (38), the excess of lactate produced by fetal structures is efficiently cleared through the placenta to the mother and converted into glucose.

In view of the quality change detected in fetal plasma after maternal infusion of any labeled compound studied, it is not possible to attribute the appearance of labeled lipids in fetal liver to their direct and unique use as lipogenic substrates. It is evident from present results, however, that $\left[\mathrm{U}-{ }^{14} \mathrm{C}\right]-\mathrm{L}$-alanine is not used by the rat fetus as a substrate for labeled fatty acid or glyceride glycerol synthesis, perhaps due to the low alanine aminotransferase activity found in fetal liver (16). This hypothesis is not in disagreement with the observed appearance of ${ }^{14} \mathrm{C}$-lactate in fetus plasma after maternal ${ }^{14} \mathrm{C}$-alanine infusion since this conversion occurs in the placenta rather than in fetal tissues (32). Unlike $\mathrm{L}$-alanine, after maternal infusions through the left uterine artery of either ${ }^{14} \mathrm{C}$-D-glucose or ${ }^{14} \mathrm{C}$-glycerol, labeled lipids appeared in fetal liver. Since this value was higher in livers of fetuses from the left than from the right uterine horn it may be concluded that the lipids were directly synthesized from the placental transferred substrate. Maternal starvation caused a reduction in the synthesis of ${ }^{14} \mathrm{C}$-fatty acids from both labeled D-glucose and glycerol, in agreement with the similar effect reported using ${ }^{3} \mathrm{H}_{2} \mathrm{O}$ as tracer (17). This effect seems to occur independently of a 
change in fetal liver lipogenic activities which have been shown to be unmodified by maternal starvation (16). It may therefore be caused by the reduced fetal availability of maternal substrates, cosubstrates, and/or effectors for this pathway which occurs in fetuses of starved mothers as a result of diminished placental metabolite transfer, which depends on maternal circulating levels and uterine blood flow.

In contrast with lipogenesis, ${ }^{14} \mathrm{C}$-glyceride glycerol synthesis was much greater in liver of fetuses from mothers infused with $\left[\mathrm{U}-{ }^{14} \mathrm{C}\right]$-glycerol than with $\left[\mathrm{U}-{ }^{14} \mathrm{C}\right]-\mathrm{D}-$ glucose and it was unmodified by maternal starvation. This finding indicates that this process occurs through the direct esterification of glycerolphosphate formed by the glycerol kinase catalyzed reaction, which is known to be active in fetus liver at late gestation (11), rather than by glycerolgenesis. In adults, glycerolgenesis from different substrates is directly correlated with gluconeogenesis $(23,39)$. Therefore the negligible glycerolgenesis found in fetal liver further supports the main conclusion of the present study concerning the absence of gluconeogenesis from either L-alanine and glycerol and even from lactate in the fed and 48-h starved rat fetus.

Acknowledgment. The authors thank Angela Murúa for excellent technical assistance.

\section{REFERENCES}

1. Arinze IJ 1975 On the development of phosphoenolpyruvate carboxykinase and gluconeogenesis in guinea pig liver. Biochem Biophys Res Commun 65:184-189

2. Mims LS 1979 Adaptive gluconeogenesis in preterm and term rabbits. Pediatr Res 13:241-245

3. Ballard FJ, Oliver IT 1965 Carbohydrate metabolism in liver from foetal and neonatal sheep. Biochem J 95:191-200

4. Adam PAJ, Schwartz AL, Rahiala EL, Kekomaki M 1978 Glucose production in midterm human fetus I. Autoregulation of glucose uptake. Am J Physiol 234:E560-E567

5. Ballard FJ, Oliver IT 1963 Glycogen metabolism in embryonic chick and neonatal rat liver. Biochim Biophys Acta 71:578-588

6. Philippidis H, Ballard FJ 1969 The development of gluconeogenesis in rat liver. Experiments in vivo. Biochem J 113:651-657

7. Provost EL, Portha B, Cros TC, Picon L 1980 Postmaturity in the rat: glucose metabolism in the fetus and the neonate. Pediatr Res 14:793-798

8. Yeung D, Oliver IT 1967 Gluconeogenesis from amino acids in neonatal rat liver. Biochem J 103:744-748

9. Yeung D, Stanley RS, Oliver IT 1967 Development of gluconeogenesis in neonatal rat liver. Effect of premature delivery. Biochem $\mathbf{J}$ 105:1229-1233

10. Gilbert M 1977 Origin and metabolic fate of plasma glycerol in the rat and rabbit fetus. Pediatr Res 11:95-99

11. Vernon RS, Walker DG 1970 Glycerol metabolism in the neonatal rat. Biochem J 118:531-536

12. Bossi E, Greenberg RE 1972 Sources of blood glucose in the rat fetus. Pediatr Res 6:765-772

13. Girard JR, Ferre P, Gilbert M, Kervran A, Assan R, Marliss EB 1977 Fetal metabolic response to maternal fasting in the rat. Am J Physiol 232:E456E463

14. Goodner CJ, Thompson DJ 1967 Glucose metabolism in the fetus in utero. The effect of maternal fasting and glucose loading in the rat. Pediatr Res 1:443-451
15. Rhoades RA, Ryder DA 1981 Fetal lung metabolism, response to maternal fasting. Biochim Biophys Acta 663:621-629

16. Diamant YZ, Shafrir E 1978 Placental enzymes of glycolysis, gluconeogenesis and lipogenesis in the diabetic rat and in starvation. Diabetologia 15:481485

17. Lorenzo M, Benito M, Medina JM 1982 Lipogenesis in vivo in maternal and foetal tissues during late gestation in starved rats. Biochem Soc Trans 10:396

18. Lasunción MA, Testar X, Palacin M, Chieri R, Herrera E 1983 Method for the study of metabolite transfer from rat mother to fetus. Biol Neonate 44:85-92

19. Hugget ASG, Nixon DA 1957 Use of glucose oxidase, peroxidase, and $O$-dianisidine in determination of blood and urinary glucose. Lancet 1:368-
370

20. Williamson DH 1974 L-Alanine determination with alanine dehydrogenase. In: Bergmeyer HU (ed) Methods of Enzymatic Analysis, 2nd ed, Vol 4. Verlag Chemie, Academic Press Inc, New York, pp 1679-1682

21. Garland PB, Randle PJ 1962 A rapid enzymatic assay for glycerol. Nature (Lond) 196:987-988

22. Passonneau JV 1974 L-(+)-Lactate determination with lactic dehydrogenase. Fluorimetric method. In: Bergmeyer HU (ed) Methods of Enzymatic Analysis, 2nd ed, Vol 3. Verlag Chemie, Academic Press Inc, New York, pp 14681472

23. Zorzano A, Herrera E 1984 Liver and kidney cortex gluconeogenesis from L-alanine in fed and starved rats. Int $\mathrm{J}$ Biochem 16:263-267

24. Chaves JM, Herrera E 1980 In vivo glycerol metabolism in the pregnant rat. Biol Neonate 37:172-179

25. Folch J, Lees M, Sloane-Stanley GH 1957 A simple method for the isolation and purification of total lipids from animal tissues. J Biol Chem 226:497509

26. Kerpel S, Shafrir S, Shapiro B 1961 Mechanism of fatty acid assimilation in adipose tissue. Biochim Biophys Acta 46:495-504

27. Hill PMM, Young M 1973 Net placental transfer of free amino acids against varying concentrations. J Physiol (Lond) 235:409-422

28. Widdas WF 1952 Inability of diffusion to account for placental glucose transfer in the sheep and consideration of the kinetics of a possible carrier. J Physiol 118:23-39

29. Zorzano A, Lasunción MA, Herrera E 1986 Role of the availability of substrates on hepatic and renal gluconeogenesis in the fasted late pregnant rat. Metabolism 35:297-303

30. Ballard FJ, Hanson RW 1967 Phosphoenolpyruvate carboxykinase and pyruvate carboxylase in developing rat liver. Biochem J 104:866-871

31. Herrera E, Palacin M, Martin M, Lasunción MA 1985 Relationship between maternal and fetal fuels and placental glucose transfer in rats with maternal diabetes of varying severity. Diabetes 34 (suppl 2):42-46

32. Palacin M, Lasunción MA, Martin del Rio R, Herrera E 1985 Placental formation of lactate from transferred L-alanine and its impairment by aminooxyacetate in the late-pregnant rat. Biochem Biophys Acta 841:90-96

33. Remesar X, Arola LI, Palou A, Alemany M 1980 Activities of enzymes involved in amino acid metabolism in developing rat placenta. Eur $\mathrm{J}$ Biochem 110:289-293

34. Palacin M, Lasunción MA, Herrera E 1983 Transfer from mother to foetus of $\mathrm{L}$-alanine and glycerol in fed and $48 \mathrm{hr}$-starved pregnant rats. Biochem Soc Trans 11:731-732

35. Mampel T, Villarroya F, Herrera E 1985 Hepatectomy-nephrectomy effects in the pregnant rat and fetus. Biochem Biophys Res Commun 131:1219-1225

36. Arizmendi C, Medina JM 1983 Lactate as an oxidizable substrate for rat brain in vitro during the perinatal period. Biochem $\mathrm{J} 214: 633-635$

37. Shambaugh GE, Koehler RA, Freinkel N 1977 Fetal fuels. II. Contribution of selected carbons fuels to oxidative metabolism in rat conceptus. Am J Physiol 233:E457-E461

38. Kraan GPB, Dias T 1975 Size of L-lactate transport from the fetal rat to the mother animal. Biol Neonate 26;9-20

39. Soley M, Chieri R, Llobera M, Herrera E 1985 Glucose infused through the portal vein enhances liver gluconeogenesis and glycogenesis from (3$\left.{ }^{14} \mathrm{C}\right)$ pyruvate in the starved rat. Int J Biochem 17:685-688 